\title{
PROSES BERPIKIR MAHASISWA DALAM MEMBUAT KONEKSI MATEMATIS PADA SOAL PEMECAHAN MASALAH
}

\author{
Anggar Titis Prayitno \\ Universitas Kuningan, Jalan Cut Nyak Dien 36A Kuningan 45513 \\ Email: anggar.titis.prayitno@uniku.ac.id
}

\begin{abstract}
ABSTRAK
Penelitian ini bertujuan mendeskripsikan proses berpikir mahasiswa dalam membuat koneksi matematis pada soal pemecahan masalah. Koneksi matematis yang dimaksud pada penelitian ini adalah aktivitas yang dilakukan mahasiswa dalam menghubungkan antar konsep matematika dalam menyelesaikan soal pemecahan masalah. Tahapan penyelesaian masalah yang digunakan berdasarkan tahapan penyelesaian masalah menurut polya.Metode penelitian yang digunakan adalah kualitatif deskriptif. Pada penelitian ini tiga mahasiswa prodi pendidikan matematika UNIKU tingkat I dipilih sebagai subjek penelitian dengan rincian masing - masing satu mahasiswa berkemampuan rendah, sedang dan tinggi. Pengumpulan data dilakukan melalui tes dan wawancara untuk mengetahui proses berpikir subjek dalam membuat koneksi matematis. Hasil analisis data menunjukkan proses koneksi subjek dengan kemampuan matematika tinggi sangat lengkap dan mampu mengaitkan beberapa konsep dalam matematika. Begitu juga subjek dengan kemampuan matematika sedang cukup lengkap dalam membuat koneksi matematika. Akan tetapi subjek S2 kurang mampu mengaitkan beberapa konsep dalam matematika. Sedangkan subjek dengan kemampuan matematika rendah tidak lengkap dalam membuat koneksi matematika. subjek S3 tidak mampu mengaitkan konsep dalam matematika serta tidak mampu menjelaskan dengan baik hasil jawaban yang diperoleh.
\end{abstract}

Kata Kunci: Proses berpikir, Kemampuan Koneksi Matematis, Pemecahan Masalah

\begin{tabular}{l} 
ABSTRACT \\
This study aims to describe the thinking process of students in making mathematical \\
connections on problem solving of problems. Mathematical connection is referred to in this \\
study is the activity that students do in connecting between mathematical concepts in solving \\
problem solving of problems. Stages of problem solving that are used based on the stages of \\
problem solving by polya.Metode of research used is qualitative descriptive. In this study, \\
three students of mathematics education program of UNIKU level were chosen as research \\
subjects with the details of each one of low, medium and high ability students. Data \\
collection is done through tests and interviews to know the subject thinking process in \\
making mathematical connections. The results of data analysis shows the process of subject \\
connection with high mathematical ability is very complete and able to link some concepts in \\
mathematics. So is the subject with mathematical ability being quite complete in making the \\
mathematical connection. However, the subject of S2 is less able to relate some concepts in \\
mathematics. While subjects with low math skills are incomplete in making mathematical \\
connections. S3 subject is not able to associate the concept in mathematics and not able to \\
explain well the results obtained answers. \\
Keywords: Thinking Process. Mathematical Connection Capability. Troubleshooting \\
\hline
\end{tabular}




\section{PENDAHULUAN}

Beberapa literatur pendidikan matematika menyebutkan bahwa untuk memperoleh pemahaman matematis, siswa diharuskan membuat hubungan antara gagasan matematika, fakta, prosedur, dan relasinya (Hiebert dan Carpenter 1992; Ma 1999; Moschkovich et al. 1993; Skemp 1978, 1989); Dengan demikian, memahami hubungan antar konsep matematis menjadi sesuatu yang penting dalam pembelajaran matematika. Hubungan atau keterkaitan antar konsep dapat dimaknai bahwa suatu konsep dapat menjadi prasyarat bagi pemahaman konsep lainnya.

Hubungan antar konsep dalam matematika maupun dengan bidang lain inilah yang disebut koneksi matematis. Kemampuan dalam membuat koneksi matematis adalah kemampuan membuat hubungan antara ide-ide matematika maupun diluar matematika untuk membangun pemahaman matematika (NCTM, 2000). Membuat koneksi adalah aktivitas manusia yang penting. Dalam penelitian mengenai cara kerja otak oleh Caine dan Caine (1990) memperoleh hasil bahwa aktivitas mencari pola dan hubungan adalah hal yang alami dalam aktivitas otak. Bagian informasi yang terpisah membutuhkan lebih banyak waktu untuk memahami daripada pengalaman belajar pengalaman yang terhubung dengan pengetahuan seseorang sebelumnya. Siswa datang ke sekolah dengan pemahaman dan pengalaman yang berbeda tentang matematika. Ketika siswa belajar yang konsep baru, mereka secara alami membuat koneksi terhadap konsep yang sudah mereka ketahui dan mengembangkan pemahaman mereka sendiri dengan cara yang masuk akal menurut mereka. Siswa dapat membuat koneksi yang tepat ke pemahaman sebelumnya, atau mereka dapat mengembangkan kesalahpahaman yang sangat sulit untuk diubah. Dalam hal ini peran guru sangat penting untuk membantu siswa membangun konstruksi yang akurat tentang ide-ide matematika dan mampu menerapkan pengetahuan mereka baik pada permasalahan rutin maupun non rutin. Ketika guru memahami pemahaman awal siswa, latar belakang siswa, kecenderungan gaya belajar, mereka dapat meningkatkan peluang memfasilitasi pemahaman matematis siswa di tingkat yang lebih tinggi.

$$
\text { Coxford }
$$

mendeskripsikan koneksi sebagai ide atau proses yang digunakan untuk menghubungkan berbagai topik dalam matematika. Coxford (1995) juga menyatakan bahwa koneksi matematika mempunyai tiga aspek yang berkaitan, yaitu: (1) tema-tema yang memadukan; (2) proses matematis; dan (3) konektor matematis. Koneksi matematis juga direpresentasikan sebagai komponen dari sebuah skema yang terhubung dari skema-skema dalam jaringan mental. Marshall (1995) mengemukakan bahwa ciri skema adalah adanya koneksi. Semakin banyak koneksi, semakin besar 
kekompakan dan kekuatan dari skema tersebut. Hiebert \& Carpenter (1992) menyatakan bahwa koneksi matematis dapat diilustrasikan sebagai jaringan terstruktur seperti jaring laba-laba. Titik simpul dari jaringan merepresentasikan informasi, sedangkan benang yang menghubungkannya menunjukkan keterkaitannya.

Koneksi matematis menjadi fokus beberapa penelitian (Eli, MohrSchroeder, \& Lee, 2011; Knuth, 2000; dan Pirasa, 2016). Eli (2011) Mendeskripsikan tipe koneksi matematis yang dibuat oleh calon guru tingkat menengah menjadi lima tipe, yaitu: categorical, procedural, characteristic, curricular dan derivation.. Knuth (2000) meneliti koneksi yang dibuat oleh siswa pada saat dihadapkan pada representasi yang berbeda (representasi aljabar dan grafis) dan hasilnya siswa memiliki kecenderungan memilih representasi aljabar. Pirasa (2016) menemukan calon guru kesulitan menghubungkan konsep geometris dengan permasalah kehidupan sehari - hari, sehingga mengakibatkan kurangnya pemberikan contoh - contoh dalam pembelajaran di kelas.

Lebih lanjut penelitian yang dilakukan Nordheimer (2011) menjelaskan bahwa masalah masalah pada bidang matematis yang berbeda sebaiknya diberikan kepada siswa agar mereka dapat mengenali dan membuat koneksi di antara ide ide matematis. Dari beberapa penelitian di atas dapat dikatakan bahwa koneksi matematis menjadi sangat penting dalam pembelajaran matematika. Koneksi yang paling berguna untuk meningkatkan kemampuan matematika siswa yaitu ketika mampu menghubungkan konsep - konsep yang terkait dengan cara yang tepat (Kilpatrick dkk., 2001). Tanpa adanya kemampuan koneksi matematis, siswa akan mengalami kesulitan dalam memahami dan menyelesaikan masalah matematika.

Stanic \& Kilpatrick (1988) mendefinisikan masalah sebagai suatu keadaan dimana seseorang melakukan tugasnya yang tidak ditemukan di waktu sebelumnya. Ini berarti, suatu tugas merupakan masalah atau tidak bergantung kepada individu dan waktu. Artinya, suatu tugas merupakan masalah bagi seseorang, tetapi mungkin bukan merupakan masalah bagi orang lain. Demikian pula suatu tugas merupakan masalah bagi seseorang pada suatu saat, tetapi bukan merupakan masalah lagi bagi orang itu pada saat berikutnya, bila orang itu telah mengetahui cara atau proses mendapatkan pemecahan masalah tersebut.

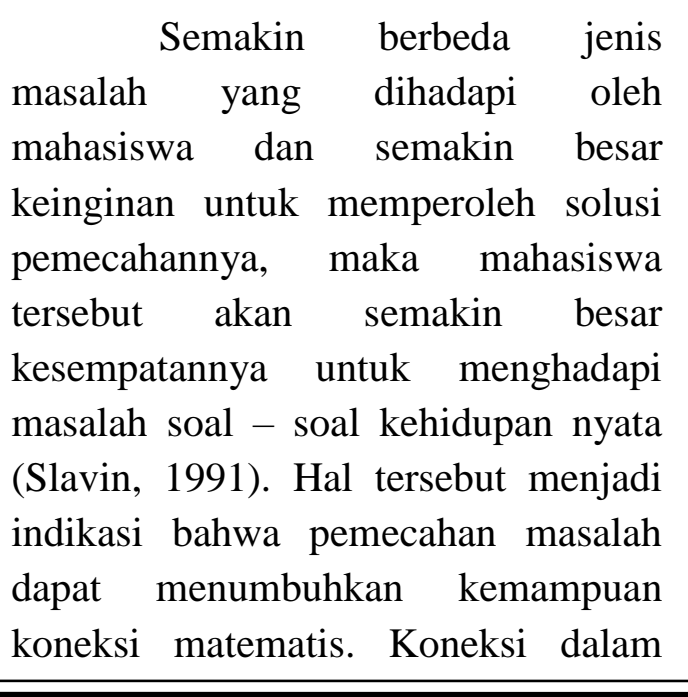


mengaitkan satu topic dengan topic lainnya, mengaitkan mata pelajaran lainnya, dan mengaitkan dengan kehidupan nyata.

Berdasarkan latar belakang di atas, penelitian ini bertujuan untuk mendeskripsikan proses berpikir mahasiswa dalam membuat koneksi matematis pada soal pemecahan masalah. Pemilihan materi bangun ruang dikarenakan materi tersebut memuat banyak koneksi matematis di dalamnya.

\section{METODE PENELITIAN}

Penelitian ini merupakan jenis penelitian kualitatif deskriptif. Fokus Penelitian ini adalah untuk mengetahui proses berpikir mahasiswa dalam membuat koneksi matematis pada soal pemecahan masalah. Subjek pada penelitian ini adalah mahasiswa prodi pendidikan matematika tingkat I dengan memilih tiga mahasiswa sebagai subjek penelitian. Pada penelitian ini tiga mahasiswa dipilih sebagai subjek penelitian, dengan rincian masing - masing satu mahasiswa berkemampuan rendah, sedang dan tinggi.

Prosedur penelitian ini meliputi tahap persiapan: penyusunan tes kemampuan koneksi matematis dan pedoman wawancara, pengumpulan data, analisis data, dan menarik kesimpulan. Peneliti berperan sebagai instrument utama pada penelitian ini. Instrumen pendukung dalam penelitian ini yaitu tes kemampuan koneksi matematis dan pedoman wawancara. Tes kemampuan koneksi matematis pada penelitian ini disajikan dalam bentuk soal cerita pada materi bangun ruang. Adapun soal tes koneksi matematis soal yang digunakan dalam penelitian ini adalah : Sebuah tempat air berbentuk kerucut. Untuk mengisi tempat itu dengan air sampai pada ketinggian $1 / 2 \mathrm{t}$ diperlukan air sebanyak 38,5 liter. Tentukan volum air yang diperlukan untuk memenuhi tempat tersebut!

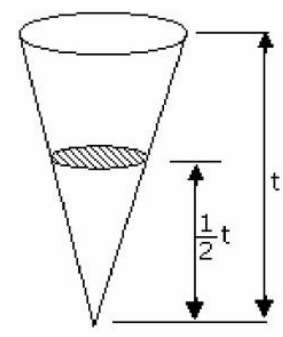

\section{Gambar 1. Soal Tes Koneksi Matematis}

\section{HASIL PENELITIAN}

Penelitian ini dikaji dan deskripsikan secara kualitatif proses berpikir mahasiswa calon guru matematika dalam memunculkan koneksi matematis pada soal pemecahan masalah. Karakteristik tiga kelompok subjek penelitian yang dipaparkan adalah kelompok mahasiswa berkemampuan matematika tinggi, sedang dan rendah. Subjek berkemampuan matematika tinggi adalah subjek 1 (S1), subjek berkemampuan matematika sedang adalah subjek 2 (S2), dan subjek berkemampuan matematika rendah 
adalah subjek 3 (S3). Proses berpikir mahasiswa dalam memunculkan koneksi matematis akan dikaji dan dideskripsikan berdasarkan kelompok subjek di atas.

\section{Proses Koneksi Matematis Subjek} Berkemampuan Matematika Tinggi

Dalam membuat koneksi antar konsep matematika, S1 mengawali dengan menggambar sketsa kerucut dan menuliskan rumus volume untuk setengah kerucut. Selanjutnya mengintegrasikan informasi yang diperoleh dari soal ke dalam bentuk matematika, yaitu jari - jari lingkaran kecil digunakan untuk menentukan volume setengah kerucut dengan tinggi $\frac{1}{2} t$. Berikut hasil pekerjaan S1dalam memahami soal dengan menuliskan informasi yang diperoleh.:

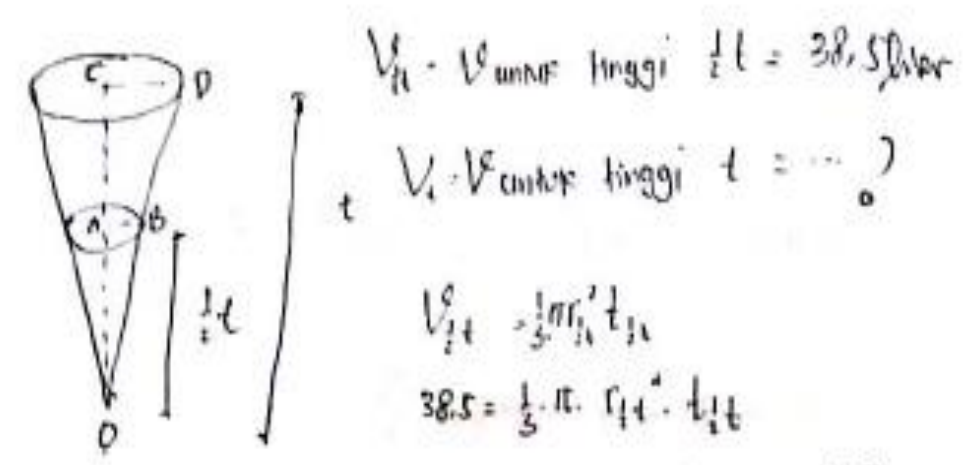

Gambar 2 Hasil Kerja S1

Tahapan berikutnya S1 mulai memikirkan untuk mencari ukuran jari - jari lingkaran kecil pada posisi tinggi setengah kerucut. S1 mampu membuat koneksi antar konsep matematika bahwa ukuran jari - jari lingkaran pada posisi $\frac{1}{2} t$ dapat ditentukan dengan konsep kesebangunan. Langkah berikutnya S1 memandang kerucut sebagai bangun datar segitiga, dimana S1 membuat perbandingan sisi - sisi pada segitiga AOB dan segitiga CAD. S1 mempu membuat koneksi dari konsep kesebangunan yang didapat dalam bentuk perbandingan sisi -sisi segitiga. Setelah menuliskan ukuran yang diketahui pada soal ke dalam perbandingan sisi - sisi, maka diperoleh ukuran jari jari lingkaran besar pada kerucut sama dengan dua kali jari - jari lingkaran kecil pada posisi $\frac{1}{2} t$. Berikut hasil pekerjaan S1 dalam menentukan ukuran jari - jari lingkaran pada posisi tinggi $\frac{1}{2} t$ dengan membuat perbandingan ukuran sisi -sisi yang sebangun: 


$$
\begin{aligned}
& \text { Perhation bohwo } \triangle \text { OA seboogun dgn } D O C D \\
& \frac{A B}{C D}=\frac{O A}{O C}=\frac{O B}{O D} \\
& \frac{r_{1}}{r_{t}}=\frac{\frac{1}{2} Y}{t} \Rightarrow 2 \cdot r_{t} t=r_{t}
\end{aligned}
$$

\section{Gambar 3 Hasil Kerja S1 Mengkoneksikan dengan Konsep Perbandingan}

Langkah terakhir yang dilakukan oleh S1 adalah menghitung volume kerucut dengan tinggi $t$. Pada tahapan ini S1 mengintegrasikan informasi yang didapat ke dalam rumus volume kerucut. Berikut hasil pekerjaan S1 dalam menentukan ukuran volume kerucut dengan tinggi $t$ :

$$
\begin{aligned}
& \therefore V \text { untik tingit } \\
&=\frac{1}{3} \cdot \pi \cdot r_{1}^{2} \cdot t_{t} \\
&=\frac{1}{3} \cdot \pi \cdot\left(2 r_{1} t\right)^{2} \cdot 2 \cdot t_{1} t \\
&=\left(\frac{1}{3}\right) \cdot 4 \cdot 2 \cdot\left(\pi \cdot r_{1}^{2} \cdot t_{1} t\right) \\
&=\frac{8}{2} \cdot 38,5 \\
&=154 \\
& \text { Volume dengan tinggi } t \text { adalah } 154 \text { liter }
\end{aligned}
$$

\section{Gambar 4 Hasil Kerja S1 dalam Menyelesaikan Permasalahan}

\section{Proses Koneksi Matematis Subjek} Berkemampuan Matematika

\section{Sedang}

Dalam membuat koneksi antar konsep matematika, S2 mengawali dengan menggambar sketsa kerucut dan menuliskan rumus volume kerucut. Selanjutnya S2 mengasumsikan bahwa jari - jari sama dengan tinggi, dimana pada saat tinggi kerucut $\frac{1}{2} t$ maka jari - jarinya adalah $\frac{1}{2} r$, dan pada saat tinggi kerucut $t$ maka jari - jarinya adalah $r$. Berikut hasil pekerjaan S2 dalam memahami soal dengan menuliskan informasi yang diperoleh.:

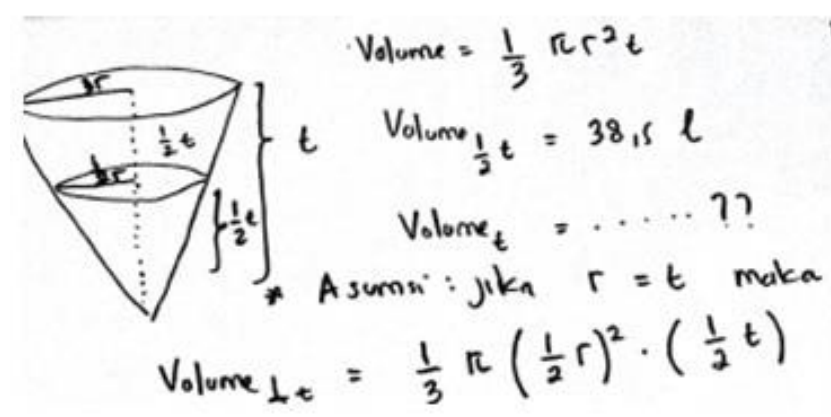

Gambar 5 Hasil Kerja S2 dalam Memahami Soal 
Selanjutnya

S2 dibuat untuk menentukan ukuran jari mengintegrasikan informasi ukuran volume setengah kerucut yang jari. Berikut hasil pekerjaan S2 dalam diperoleh dari soal dan asumsi yang menentukan volume kerucut :

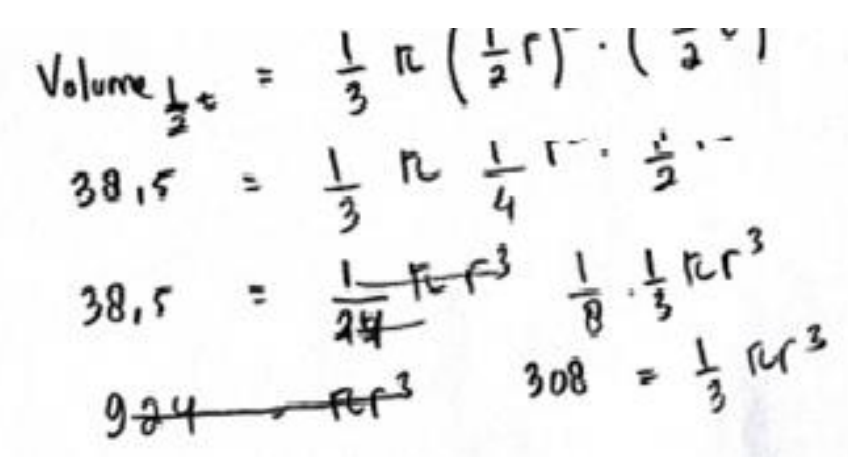

\section{Gambar 6 Hasil Kerja S2 dalam Menentukan Volume Kerucut}

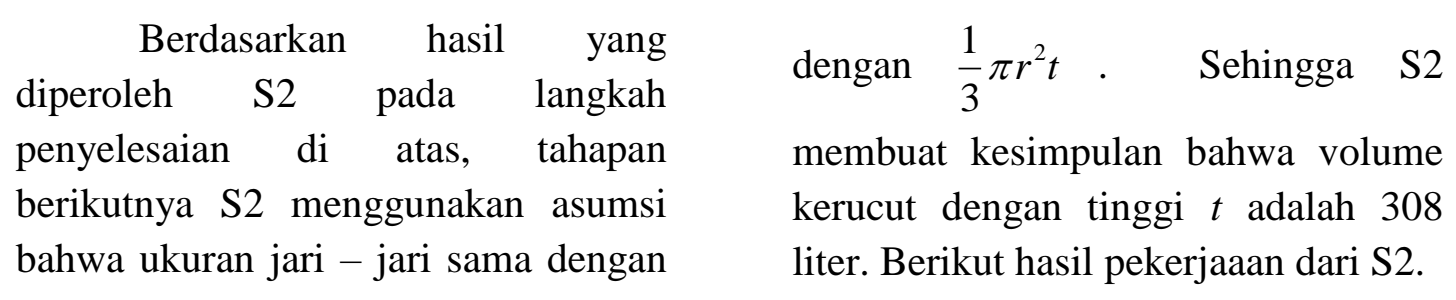
tinggi maka $\frac{1}{3} \pi r^{3}$ dianggap sama

$$
\begin{aligned}
& \text { Jadi Volume ar yg dipertiken } 4 \text { memenum. iner" } \\
& \text { adalath } \\
& V_{\text {oluie } t}=\frac{1}{3} r r t^{2} \rightarrow t=r \\
& =\frac{1}{3} R r^{3} \\
& =308 l
\end{aligned}
$$

\section{Gambar 7 Hasil Kerja S2 dalam Menghitung Volume Kerucut}

Berdasarkan jawaban penyelesaian masalah, terlihat bahwa S2 tampak kesulitan mengaitkan antar konsep dalam matematika. S2 tidak mampu mengaitkan konsep bangun ruang dengan konsep kesebangunan. Subjek S2 hanya membuat asumsi bahwa jari -jari lingkaran sama dengan tinggi kerucut (asumsi salah) sehingga jawaban yang dihasilkan juga salah.

\section{Proses Koneksi Matematis Subjek Berkemampuan Matematika Rendah}

Dalam membuat koneksi antar konsep matematika, S3 mengawali dengan menggambar sketsa kerucut. S3 tampak kesulitan memahami informasi dalam soal dan tidak 
memiliki ide penyelesaian masalah yang jelas. S3 membuat persamaan matematika antara volume kerucut 1 dengan tinggi $\frac{1}{2} t$ dan volume kerucut 2 denga tinggi $t$. S3 menyimpulkan

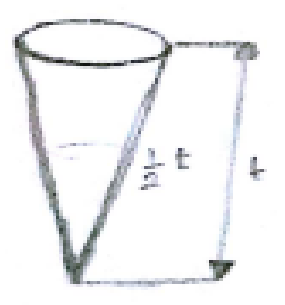

bahwa volume kerucut dengan tinggi $t$ merupakan dua kali volume kerucut dengan tinggi $\frac{1}{2} t$. Berikut hasil penyelesaian yang dilakukan oleh S3.

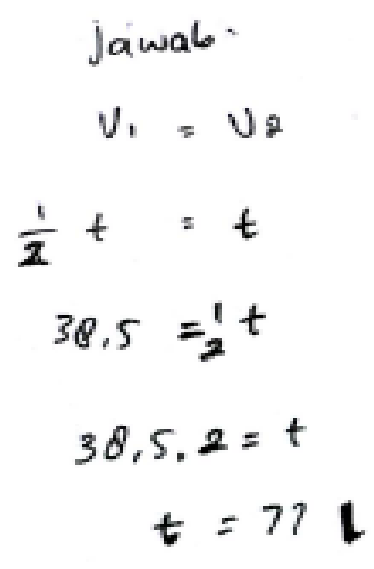

Gambar 8 Hasil Kerja S3

Berdasarkan jawaban penyelesaian masalah, terlihat bahwa S3 tampak kesulitan mengaitkan antar konsep dalam matematika. S3 tidak mampu mengaitkan konsep bangun ruang dengan konsep matematika lainnya. Subjek S3 hanya membuat kesimpulan bahwa volume kerucut dengan tinggi $t$ merupakan dua kali volume kerucut dengan tinggi $\frac{1}{2} t$.

\section{Perbandingan Proses Koneksi} Matematis Subjek Berkemampuan Matematika Tinggi, Sedang dan Rendah

Kesamaan proses koneksi subjek dengan kemampuan matematika tinggi dan sedang adalah mampu melakukan proses koneksi dengan memahami permasalahan yang diberikan, merencanakan penyelesaian dan melaksanakan penyelesaian sesuai rencana masing - masing. Subjek dengan kemampuan rendah tampak kurang mampu memahami permasalahan yang diberikan dang tidak memiliki rencana penyelesaian yang jelas.

$\begin{array}{lrr} & \text { Perbedaan proses koneksi } \\ \text { subjek } & \text { dengan } & \text { kemampuan }\end{array}$
matematika tinggi, sedang dan rendah. Subjek dengan kemampuan tinggi dan sedang mampu menggunakan pemahaman yang dimiliki untuk menyelesaikan permasalahan yang ada, sedangkan subjek dengan kemampuan matematika rendah belum mampu menggunakan pemahaman yang dimiliki tampak kesulitan dalam merencanakan penyelesaian masalah.

\section{Pembahasan}

Proses koneksi subjek dengan kemampuan matematika tinggi sangat lengkap dalam membuat koneksi antar konsep matematika yaitu: mampu 
memahami permasalahan yang diberikan dengan baik, merencanakan penyelesaian masalah, melaksanakan penyelesaian dan melakukan pengecekan kembali hasil pekerjaanya. Dalam membuat koneksi antar konsep matematika, subjek S1 mampu mengaitkan beberapa konsep dalam matematika, diantaranya konsep bangun ruang, konsep kesebangunan dan konsep perbandingan. S1 mampu menemukan perbandingan sisi yang tepat untuk mendapatkan volume kerucut.

Proses koneksi subjek dengan kemampuan matematika sedang cukup lengkap dalam membuat koneksi matematika yaitu: mampu memahami permasalahan yang diberikan, merencanakan penyelesaian masalah, melaksanakan penyelesaian dan melakukan pengecekan kembali hasil pekerjaanya. Dalam membuat koneksi antar konsep matematika, subjek S2 kurang mampu mengaitkan beberapa konsep dalam matematika. Subjek S2 hanya membuat asumsi perbandingan antara jari - jari dan tinggi kerucut. Asumsi yang dibuat oleh S2 kurang tepat, terbukti dari jawaban yang dihasilkan salah.

Proses koneksi subjek dengan kemampuan matematika rendah tidak lengkap dalam membuat koneksi matematika yaitu: mampu memahami permasalahan, tidak memiliki rencana penyelesaian masalah yang jelas, melaksanakan penyelesaian dan tidak melakukan pengecekan kembali hasil pekerjaanya. Jika siswa tidak memahami kata - kata yang ada pada soal dengan baik, mereka tidak akan dapat menyelesaikan persoalan tersebut dengan benar (Gooding, 2009; Tambychik \& Meerah, 2010; Acosta-tello, 2010; Sepeng \& Sigola, 2013). Dalam membuat koneksi antar konsep matematika, subjek S3 tidak mampu mengaitkan konsep dalam matematika. Subjek S3 tidak mampu menggunakan konsep yang dimiliki dengan baik. Subjek S3 hanya membuat asumsi perbandingan tinggi kerucut dengan volume kerucut. sehingga jawaban yang dihasilkan masih salah. Subjek S3 juga tidak mampu menjelaskan dengan baik hasil jawaban yang diperoleh, S3 tampak ragu dengan jawaban yang dihasilkan.

\section{KESIMPULAN}

Berdasarkan hasil kajian terhadap proses koneksi matematis pada soal pemecahan masalah dapat disimpulkan sebagai berikut:

1. Proses koneksi subjek dengan kemampuan matematika tinggi sangat lengkap dalam membuat koneksi antar konsep matematika. Subjek S1 mampu mengaitkan beberapa konsep dalam matematika, diantaranya konsep bangun ruang, konsep kesebangunan dan konsep perbandingan.

2. Proses koneksi subjek dengan kemampuan matematika sedang cukup lengkap dalam membuat koneksi matematika. Akan tetapi subjek S2 kurang mampu mengaitkan beberapa konsep dalam matematika.

3. Proses koneksi subjek dengan kemampuan matematika rendah 
tidak lengkap dalam membuat koneksi matematika. subjek S3 tidak mampu mengaitkan konsep dalam matematika serta tidak mampu menjelaskan dengan baik hasil jawaban yang diperoleh.

\section{DAFTAR PUSTAKA}

Acosta-Tello, E. (2010). Making mathematics word problems reliable measures of student mathematics abilities. Journal of Mathematics Education, 3(1), 15-26.

Bell, Frederick H. (1978). Teaching and Learning Mathematics in Secondary School. Cetakan kedua. Dubuque, Iowa: Wm. C. Brown Company Publishers.

Caine, R. N., \& Caine, G. (1990). Understanding a brain-based approach to learning and teaching. Educational Leadership, 48(2), 66-70.

Coxford, A. F. 1995. The Case for Connections. Dalam Peggy A. Hourse \& Arthur F. Coxford (Eds), 1995 Yearbook, Connecting Mathematics Across The Curriculum (hlm. 3-12). Reston, VA: The National Council of Theachers of Mathematics, Inc.

Eli, J. A., Mohr-Schroeder, M. J., \& Lee, C. W. (2011). Exploring mathematical connections of prospective middle-grades teachers through card-sorting tasks. Mathematics Education Research Journal, 23(3), 297.
Gooding, S. (2009). Children's difficulties with mathematical word problems. Proceedings of the British Society for Research into Learning Mathematics, 29(3), 31-36.

Hiebert, J. \& Carpenter, T. P. 1992. Learning and Teaching with Understanding. Dalam D. A. Grouws (Ed.), Handbook of Research on Mathematics Teaching and Learning, (hlm. 65 - 97). New York: Macmillan Publishing Company.

Kilpatrick, J.,Swafford, J.,\& Findel, B. (2001). Adding It Up : Helping Children Learn Mathematics. Washington, DC : National Academy - Press.

Knuth, E. J. (2000). Student understanding of the Cartesian connection: An exploratory study. Journal for Research in Mathematics Education, 500507.

Marshall, S. P. 1995. Schemas in Problem Solving. New York: Cambridge University Press.

National Council of Teachers of Mathematics [NCTM]. (2000). Principles and standards for school mathematics. Reston: National Council of Teachers of Mathematics.

Nordheimer, S. (2011). Mathematical Connections At School:understanding and facilitating connections in mathematics. Diakses dari : http://didaktik.math.huberlin.de/files/mathematical_con nections_1.pdf.[4 Juni 2017] 
Pirasa, N. (2016). The Connection Competencies of Pre-Service Mathematics Teachers about Geometric Concepts to DailyLife. Universal Journal of Educational Research, 4(12), 2840-2851.

Sepeng, P., \& Sigola, S. (2013). Making sense of errors made by learners in mathematical word problem solving. Mediterranean Journal of Social Sciences, 4(13), 325.

Slavin, R. E. (1991). Synthesis of research of cooperative learning. Educational leadership, 48(5), 71-82.
Stanic, G. M. A., \& Kilpatrick, J. (1988). Historical perspectives on problem solving in mathematics curriculum. In R. I. Charles \& E. A. Silver (Eds.), Research agenda for mathematics education: The teaching and assessing of mathematical problem solving (pp. 1-22). Reston, VA: National Council of Teachers of Mathematics.

Tambychik, T., \& Meerah, T. S. M. (2010). Students' Difficulties in Mathematics Problem-Solving: What do they Say?. Procedia-Social and Behavioral Sciences, 8, 142-151. 